University of Louisville

ThinkIR: The University of Louisville's Institutional Repository

\title{
8-2011
}

\section{The effect of tissue damage and inflammation on gene expression in sensory neurons.}

Sean Anthony Trusty 1984-

University of Louisville

Follow this and additional works at: https://ir.library.louisville.edu/etd

\section{Recommended Citation}

Trusty, Sean Anthony 1984-, "The effect of tissue damage and inflammation on gene expression in sensory neurons." (2011). Electronic Theses and Dissertations. Paper 1462.

https://doi.org/10.18297/etd/1462

This Master's Thesis is brought to you for free and open access by ThinkIR: The University of Louisville's Institutional Repository. It has been accepted for inclusion in Electronic Theses and Dissertations by an authorized administrator of ThinkIR: The University of Louisville's Institutional Repository. This title appears here courtesy of the author, who has retained all other copyrights. For more information, please contact thinkir@louisville.edu. 
THE EFFECT OF TISSUE DAMAGE AND INFLAMMATION ON GENE EXPRESSION IN SENSORY NEURONS

\author{
By \\ Sean Anthony Trusty \\ B.S., University of Kentucky, 2007

\begin{abstract}
A Thesis
Submitted to the Faculty of the

School of Medicine of the University of Louisville

in Fulfillment of the Requirements

for the Degree of

Master of Science

University of Louisville

Louisville, Kentucky
\end{abstract} \\ Department of Anatomical Sciences and Neurobiology
}

August 2011 



\title{
THE EFFECT OF TISSUE DAMAGE AND INFLAMMATION ON GENE EXPRESSION IN SENSORY NEURONS
}

\author{
By \\ Sean Anthony Trusty \\ B.S., University of Kentucky, 2007
}

A Thesis Approved on

July, 15, 2011

By the following Thesis Committee:

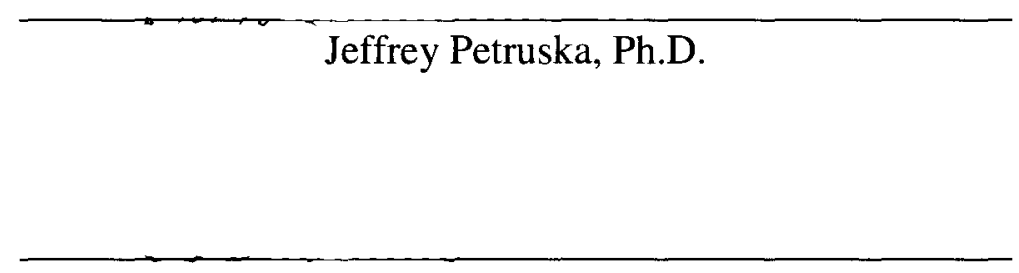

Charles Hubscher, Ph.D.

Radhika Vaishnav, Ph.D. 


\title{
DEDICATION
}

This thesis is dedicated to my parents

\author{
Mr. Anthony Trusty \\ and \\ Mrs. Lucy Trusty \\ who have given me the opportunity to pursue \\ my education and my dreams.
}




\section{ACKNOWLEDGMENTS}

I would like to thank my mentor, Dr. Jeff Petruska for his teaching and his guidance over the last two years. I would also like to thank my other committee members, Dr. Charles Hubscher and Dr. Radhika Vaishnav for their comments and assistance with my project over the last two years. Without there help I could not have achieved my goals. I would like to thank my fellow Petruska lab members, Dr. Kris Rau, Dr. Ben Harrison, Tyler Hougland, Sarah Couch and Gayathri Rajan. I would also like to thank my fellow Hubscher lab members, Jill Ward and Jim Armstrong for their help along the way. I would also like to thank my parents and my sister Amy for keeping me focused on the future and my goals I am working toward. 


\title{
ABSTRACT \\ THE EFFECT OF TISSUE DAMAGE AND INFLAMMATION ON GENE EXPRESSION IN SENSORY NEURONS
}

\author{
Sean A Trusty
}

July 15,2011

This study examined the effects of tissue damage and inflammation on the expression in sensory neurons of $\mathrm{P} 2 \mathrm{X} 3$, a gene that has a role in nociception and sensing bladder distension, which is regulated by nerve injury. Tissue damage induces expression of ATF3, an indicator of injury, in sensory neurons. Animals were exposed to different types of tissue damage including single and repeated skin incision, bladder incision and a spinal cord injury with bladder inflammation. P2X3 was regulated differentially between conditions of single and repeated skin incision. One condition that involves repeated tissue damage and alteration of bladder function is spinal cord injury. In a small study of SCI and bladder inflammation we found no change in P2X3 expression in sensory neurons. Changes in expression of genes like P2X 3 could have implications for bladder dysfunction and altered nociception. 


\section{TABLE OF CONTENTS}

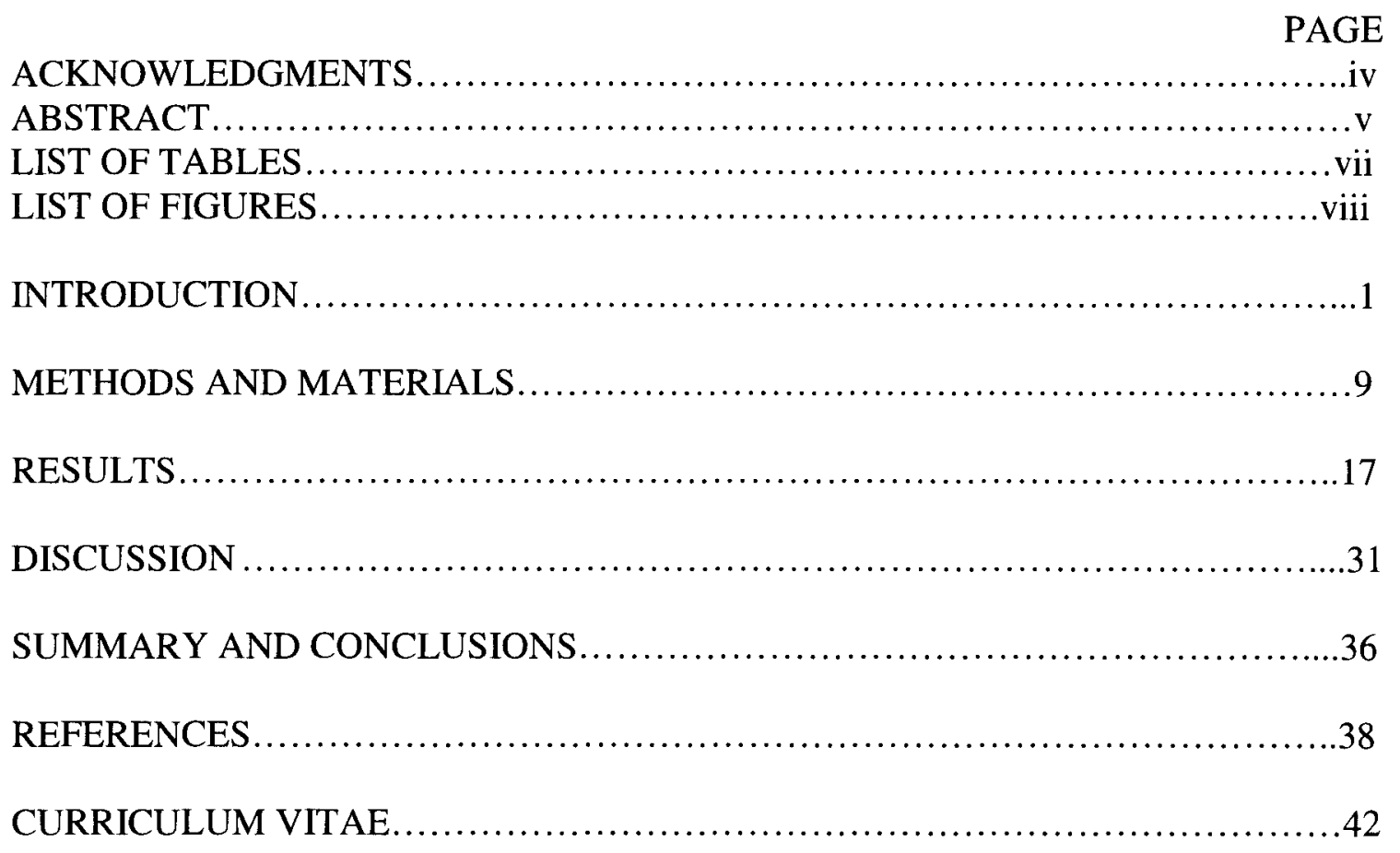




\section{LIST OF TABLES}

TABLE

PAGE

1. Single Skin Incision Time Table ............................................ 10

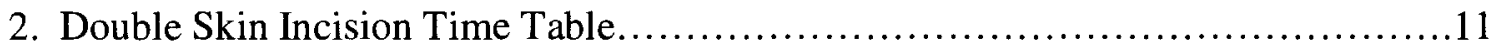

3. SCI + Bladder Inflammation Time Table ................................... 14

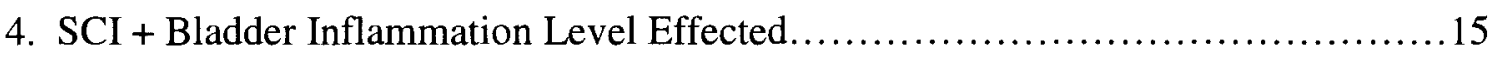

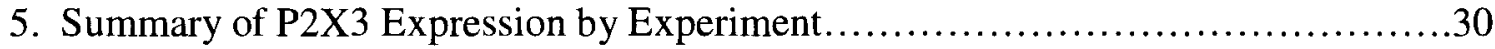




\section{LIST OF FIGURES}

FIGURE

PAGE

1. Single Skin Incision P2X3 mRNA Expression.................................17

2. Double Skin Incision P2X3 mRNA Expression.................................19

3. 14 Day Single Skin Incision vs. $14+4$ Day Double Skin Incision...................20

4. 28 Day Single Skin Incision vs. $28+4$ Day Double Skin Incision...................21

5. $\mathrm{P} 2 \mathrm{X} 3$ mRNA Expression in L1/L2 DRG Following Bladder Incision...............22

6. ATF3 mRNA Expression in L1/L2 DRG Following SCI + Bladder Inflammation....24

7. P2X3 mRNA Expression in L1/L2 DRG Following SCI + Bladder Inflammation....25

8. ATF3 mRNA Expression in L6/S1 DRG Following SCI + Bladder Inflammation....26

9. P2X3 mRNA Expression in L6/S1 DRG Following SCI + Bladder Inflammation....27

10. ATF3 mRNA Expression in Nodose Ganglia Following

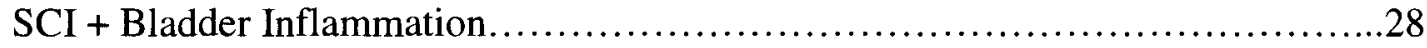

11. $\mathrm{P} 2 \mathrm{X} 3 \mathrm{mRNA}$ Expression in Nodose Ganglia Following $\mathrm{SCI}+$ Bladder Inflammation. 


\section{INTRODUCTION}

Nociception is defined as the neural processes of encoding and processing noxious stimuli - those stimuli that are damaging or potentially-damaging, and normally give rise to a sensation of pain. Nociceptive sensory neurons are responsible for transmitting messages to the spinal cord that a stimulus is noxious and could potentially lead to tissue damage (Julius and Basbaum, 2001). An important thing to realize is that while a noxious stimulus may trigger an action potential it is just that, an electrical signal, and must be processed by the brain to become perceived as pain. Nociception does not necessarily equal pain. This work considers some mechanisms of changes in nociception that can arise after tissue damage occurs.

Tissue damage is an every day risk for each of us. It can be as insignificant as a little abrasion on your knee or as severe as a major trauma such as a gun shot wound. We hope to avoid all of the tissue damage we possibly can, however we will all incur some tissue damage at some point in our lives.

Tissue damage can come in many forms and it often leads to pain (Julius and Basbaum, 2001). In addition to pain tissue damage can also affect sensory neurons causing gene expression changes that are similar to nerve injury. Incising the cutaneous tissue without cutting a nerve mimics nerve injury by inducing the expression of ATF3 in the cell bodies of neurons in the dorsal root ganglia (Hill et al., 2010). Cutaneous tissue incision also leads to up regulation of neuronal regenerative markers (Hill et al., 2010). 
Other studies have also shown that peripheral application of noxious chemicals such as capsaicin, formalin, mustard oil and menthol activate ATF3 in neurons (Braz and Basbaum, 2010). These two studies may imply that injury to axons in tissue without injury to the nerve itself may be adequate to lead to an injury-like response in the neurons.

Following injury to neurons certain processes can lead to sensitization. This sensitization can take the form of increased response to stimuli and/or lowered threshold to stimuli (i.e. hyperalgesia) and possibly play a role in making non-noxious stimuli become noxious (i.e. allodynia) (Basbaum and Woolf, 1999). These stimuli are transduced and communicated to the spinal cord in the form of action potentials fired from sensory neurons (Julius and Basbaum, 2001). Sensitization results in increased action potential frequency.

Injury to sensory neurons induces a priming effect in terms of axonal regeneration. That is, a second injury to the neuron results in a greater amount of axonal regeneration (Neumann et al., 2005). This will be referred to as anatomical priming. However, this is not the only form of priming that may occur. Another form of priming can occur from prolonged inflammation leading to nociceptor sensitization. Priming can be caused by release of proinflammatory mediators, which includes prostogladin E2 and adenosine (Ferrari et al., 2010) and we will call this neurochemical priming. Injury and inflammation can lead to priming of sensory neurons that not only cause increased expression of genes related to axonal regeneration but also neuroplastic changes. 
Gene changes that occur after injury to sensory neurons can be important in terms of nociception. These changes can be reflected in neuronal anatomy, neurochemistry and function (i.e. transduction and signaling). A gene that is important for nociceptive transduction is purinoreceptor 3 , or $\mathrm{P} 2 \mathrm{X} 3$. $\mathrm{P} 2 \mathrm{X} 3$ receptors on axon terminals in the periphery bind ATP released from peripheral tissues and transduce a signal by nociceptive neurons that can be carried by primary afferent neurons to the spinal cord and on to the brain to be perceived as painful (Hamilton and McMahon, 2000, Chizh and Illes, 2001, North, 2004). P2X3 has also been found to play a role in different pain states including inflammatory, neuropathic and visceral pain (Chizh and Illes, 2001). Knockout mouse studies have demonstrated a vital role for $\mathrm{P} 2 \mathrm{X} 3$ in peripheral nociception as well as bladder function. P2X3 knockout mice have reduced pain related behavior when ATP and noxious chemicals such as formalin are injected into the hind paw (Cockayne et al., 2000).

P2X3 knockout mice also exhibit largely distended bladders, bladder hyporeflexia, and decreased voiding frequency (Cockayne et al., 2000) associated with a reduced capacity for transducing the ATP-mediated signal of distension. Normal bladder function relies on peripheral receptors and a nervous system circuit to monitor bladder fullness so we can determine when it is time to "go." The bladder is a hollow organ with a urothelium and a muscular wall. When the bladder is filling the walls begin to stretch to accommodate the increased amount of urine that is filling the bladder. As the walls stretch the urothelium releases ATP to signal distension (Burnstock, 2009). A purinoreceptor P2X3, binds ATP and transduces the release of ATP into a neural signal (Dunn et al., 2001) that is carried by primary afferents to the spinal cord and brain to tell 
us, "my bladder is getting full." While P2X3 binds ATP and transmits the signal of stretch in the bladder, as well as being expressed by some nociceptors, which transmit primary sensory information to the spinal cord and brain which could be perceived as pain (Cook and McCleskey, 2000, Burnstock, 2009). The characteristics of the P2X3 knockout mouse indicate a vital role for $\mathrm{P} 2 \mathrm{X} 3$ in nociception and bladder function. One condition which caries issues of enhanced nociception and pain, repeated tissue damage and bladder dysfunction is spinal cord injury.

Every year approximately 12,000 people suffer a spinal cord injury (Center, 2011). Loss of locomotion is a very severe consequence that occurs after spinal cord injury (SCI), however that is only one of the multiple problems the individual will face following injury that will decrease the individual's quality of life. Other problems facing the patient include the possible loss of sensory and autonomic functions below the level of the injury. Bladder and sexual dysfunction of the injured patient rank among the top problems affecting the SCI population (Anderson, 2004). In addition to affecting quality of life, mortality is also affected with an individual with a spinal cord injury being 11 times more likely to die of diseases of the urinary system than individuals without SCI (DeVivo MJ, 1995).

Incontinence, the need for catheters and the infections associated with them are troublesome issues a SCI patient must face following injury itself. In addition to these issues of the urinary system is the incidence of pelvic pain in some individuals following the injury. While every SCI is unique in terms of level and mechanism of injury, many individuals face some kind of sensory deficit below the level of the injury. Spinal cord injured individuals also face many potential sources of tissue damage. Reoccurring need 
for catheters and pressure sores often plague the individual (McKinley et al., 1999). While non SCI individuals occasionally encounter these same issues their nervous system is able to sense noxious stimuli allowing them to perceive the symptoms and seek the necessary treatment to alleviate these issues and treat them without incurring many complications such as systemic infections and tissue damage. Non SCI individuals also have descending pain-modulation circuitry which can suppress the effect of the input from nociceptors on the spinal cord (Sandkuhler, 1996, Gebhart, 2004).

While the SCI patient often does not have sensation below the level of the injury, it does not mean that stimuli and the resultant sensory input to the spinal cord cease to exist. While the message is not making it to the brain to tell you "ouch that hurts," the message is still being sent by sensory neurons and processed by the spinal cord. While the painful stimulus exists the nociceptors are stilling working hard doing their job sending a message that will never be received by the brain. Reoccurring urinary tract infections, gastro intestinal problems and bedsores are just a few of the stimuli leading to the triggering of nociceptors. These signals while not producing the pain that a non-SCI patient would feel are not occurring without consequence. Nociceptive input can lead to sensitization and serious conditions such as autonomic dysreflexia. Autonomic Dysreflexia is triggered by changes in the sensory neurons after repeated signaling that allows a stimulus such as bladder distension to become the trigger for a dangerous rise in blood pressure that can cause severe and even fatal myocardial infarctions and strokes (Teasell et al., 2000). Bladder over distension is only one of the noxious stimuli that can cause autonomic dysreflexia to occur. Other conditions that can lead to autonomic 
dysreflexia that an SCI individual may have are urinary tract infections and pressure sores (Teasell et al., 2000).

Following SCI, many changes such as bladder hypertrophy, detrusor hyperreflexia, urinary tract infections and neurogenic bladder dysfunction come about in the urinary system (Lu et al., 2007). These changes may lead to repeated noxious stimuli leading to the sensitization of not only the bladder but also the sensory innervation to the bladder itself. Many of these changes can affect the sensory afferents of the bladder. The plasticity of sensory neurons may be caused by neurotrophic factors such as NGF that is at a higher concentration in bladder tissue after SCI (de Groat and Yoshimura, 2010). This plasticity can affect the neurons in many different ways, altering them morphologically, chemically and electrically (de Groat and Yoshimura, 2010). Urinary tract infections, detrusor hyperreflexia, autonomic dysreflexia, as well as neurogenic bladder dysfunction occur after SCI. It is also known that after SCI, the bladder is hypertrophied and has increased capacity (Lu et al., 2007). Combined with these morphological changes in the bladder, hypersensitivity in neurons can lead to changes in sensory input from the bladder. The changes that can occur in sensory neurons of an inflamed bladder are increased excitability and sensitization of the neurons innervating the bladder (Dang et al., 2008).

Two spinal cord regions receive sensory innervation/information from the bladder. The L1 and L2 spinal segments receive sensory innervation from the dome of the bladder while L6 and S1 receive innervation from the wall of the bladder (Applebaum et al., 1980). The L6 and S1 spinal segment receives information from the pelvic nerve, which is important for the sensation of bladder distention. The L1 and L2 segment 
receives information from the hypogastric nerves and it responds to bladder distension as well as being more responsive to chemical irritation/damage than the pelvic nerve (Moss et al., 1997).

The role of $\mathrm{P} 2 \mathrm{X} 3$ in nociceptive signaling has been outlined in both visceral and somatic systems. P2X3 expression levels have been shown to vary following injury to peripheral neurons (Tsuzuki et al., 2001), which results in the induction of activating transcription factor (ATF3) (Tsujino et al., 2000). What is interesting about P2X3 and $\mathrm{ATF} 3$ is that they may have a relation to one another. The gene coding for $\mathrm{P} 2 \mathrm{X} 3$ has a putative binding site for ATF3 (Subramanian et al., 2005). Thus, P2X3 may be regulated in some manner by ATF3 activation following injury to neurons. It was shown that following peripheral nerve injury that while mRNA levels of $\mathrm{P} 2 \mathrm{X} 3$ in the entire dorsal root ganglion may be elevated, P2X3 expression in neurons that also expressed ATF3 was greatly reduced (Tsuzuki et al., 2001). Thus, non-injured neurons in the same dorsal root ganglia as the neurons that were injured can increase P2X3 mRNA expression while the injured neurons decrease $\mathrm{P} 2 \mathrm{X} 3$ expression.

This study examines the changes in gene expression of a transcription factor ATF3 and a nociceptive related transduction channel P2X3 in various tissue injury conditions. The expression of genes such as ATF3 is a good indicator of neuronal injury because it is absent before injury, and ATF3 is required for successful regeneration (Stam et al., 2007). Various single cutaneous tissue incision time points as well as multiple incisions examined to see what effect they may have on neurons in terms of injury and nociception. Bladder incision in an animal without SCI will also be examined to see what effect visceral tissue damage has on sensory neurons. A SCI plus inflammation 
study will examine the effect that SCI and inflammation has on neurons innervating the bladder in terms of neuronal injury and the expression of nociceptive markers.

The question we study is what happens to those markers of nociception and neuronal injury after injury and inflammation in cutaneous tissue and the bladder. The hypothesis is that following injury to the bladder and cutaneous tissue that gene expression will be affected with ATF3 being expressed by injured neurons and P2X3 being down regulated after tissue damage and that after repeated injury and inflammation that $\mathrm{P} 2 \mathrm{X} 3$ expression will be reduced even more. 


\section{MATERIALS AND METHODS}

All animal procedures were reviewed and approved by the Institutional Use and Care Committee and carried out at the University of Louisville, School of Medicine.

\section{Single Skin Incision}

For the single skin incision study, a $3 \mathrm{~cm}$-long rostrocaudal incision was made $1 \mathrm{~cm}$ to the right of midline in the dorsal thoracic hairy skin ( T3-T8 dermatome; including the attached underlying cutaneous trunci muscle). This location prevented accidental injury to the dorsal cutaneous nerves themselves. The skin was then closed with surgical staples. Animals received Lacrilube ointment in their eyes, an intramuscular injection of $0.1 \mathrm{cc}$ gentamycin (left gastrocnemius muscle), an intraperotineal injection of 5 cc lactated Ringer's solution, and Animax antibacterial/antifungal ointment applied directly to the wound. Different time points were allowed to pass following skin incision before the animal was sacrificed and the dorsal root ganglia corresponding to the incision were collected. The time points were $4,7,14,28$ days after incision. The dorsal root ganglia RNA was extracted converted to cDNA and was then run for PCR for the gene P2X3. 
Table 1: Single Skin Incision Time Table

\begin{tabular}{|c|c|c|c|c|c|}
\hline $\begin{array}{l}\text { Single } \\
\text { Skin } \\
\text { Incision }\end{array}$ & $\begin{array}{l}\text { Treatment } \\
\text { Dates }\end{array}$ & & & & \\
\hline Groups & Day 0 & Day 4 & Day 7 & Day 14 & Day 28 \\
\hline $\begin{array}{l}\begin{array}{l}4 \text { Day } \\
n=3\end{array}\end{array}$ & Skin Incision & $\begin{array}{l}\text { Tissue } \\
\text { Retrieval }\end{array}$ & & & \\
\hline $\begin{array}{l}7 \text { Day } \\
n=3\end{array}$ & Skin Incision & & $\begin{array}{l}\text { Tissue } \\
\text { Retrieval }\end{array}$ & & \\
\hline $\begin{array}{l}14 \text { Day } \\
n=3\end{array}$ & Skin Incision & & & $\begin{array}{l}\text { Tissue } \\
\text { Retrieval }\end{array}$ & \\
\hline $\begin{array}{l}28 \text { Day } \\
n=3\end{array}$ & Skin Incision & & & & $\begin{array}{l}\text { Tissue } \\
\text { Retrieval }\end{array}$ \\
\hline $\begin{array}{l}\text { Naïve } \\
\mathrm{n}=3\end{array}$ & $\begin{array}{l}\text { Tissue } \\
\text { Retrieval }\end{array}$ & & & & \\
\hline
\end{tabular}

\section{Bladder Incision}

For the bladder incision study, a total of four naïve animals underwent an

abdominal surgery to incise the dome of the bladder with microscissors. The L1/L2

dorsal root ganglia were collected. RNA was extracted turned into cDNA and qPCR was run for the gene P2X3. Naïve n of 3 .

\section{Double Incision}

For the initial injury, a $3 \mathrm{~cm}$-long rostrocaudal incision was made $1 \mathrm{~cm}$ to the right of midline in the dorsal thoracic hairy skin ( T3-T8 dermatome; including the attached underlying cutaneous trunci muscle). This location prevented accidental injury to the 
dorsal cutaneous nerves themselves. For animals receiving two injuries, a second skin incision was made, $1 \mathrm{~mm}$ lateral from the initial incision, at either 14 days or 28 days after the intial incision. The skin was then closed with surgical staples. Animals received Lacrilube ointment in their eyes, an intramuscular injection of $0.1 \mathrm{cc}$ gentamycin (left gastrocnemius muscle), an intraperotineal injection of $5 \mathrm{cc}$ lactated Ringer's solution, and Animax antibacterial/antifungal ointment applied directly to the wound. Four days after the second incision was made the animals were sacrificed and the dorsal root ganglia corresponding to the incised skin were collected.

Table 2: Double Skin Incision Time Table

\begin{tabular}{|l|l|l|l|l|l|}
\hline $\begin{array}{l}\text { Double Skin } \\
\text { Incision }\end{array}$ & Day 0 & Day 14 & Day 18 & Day 28 & Day 32 \\
\hline Groups & $\begin{array}{l}\text { Skin } \\
\text { Incision } \\
\text { 14+4 Day }\end{array}$ & $\begin{array}{l}\text { Repeat } \\
\text { Incision }\end{array}$ & $\begin{array}{l}\text { Tissue } \\
\text { Retrieval }\end{array}$ & & \\
\hline $\begin{array}{l}28+4 \text { Day } \\
\mathrm{n}=7\end{array}$ & $\begin{array}{l}\text { Skin } \\
\text { Incision }\end{array}$ & $\begin{array}{l}\text { Tissue } \\
\text { Retrieval }\end{array}$ & & $\begin{array}{l}\text { Repeat } \\
\text { Incision }\end{array}$ & $\begin{array}{l}\text { Tissue } \\
\text { Retrieval }\end{array}$ \\
\hline Naïve $\mathrm{n}=4$ & & & & \\
\hline
\end{tabular}

\section{Spinal Cord Injury}

In the Spinal Cord Injury with Bladder Inflammation study 12 male Wistar rats were used in the study. A total of 8 of the 12 rats received a T8 spinal cord transection on day 1 of the study with the other 4 being naïve. Eight animals were anesthetized with a mixture of ketamine $(80 \mathrm{mg} / \mathrm{kg}$ body weight; Fort Dodge Animal Health, Fort Dodge, IA) and xylazine (10 mg/kg body weight; Akorn Inc, Decatur, IL) injected 
intraperitoneally. The spinal cord was exposed by laminectomy of the $\mathrm{T} 7$ vertebra, which lies over the T8 portion of the spinal cord. Spinal cord transection was made using microscissors to make a complete transverse lesion of the cord. The lesion was inspected following the transection to insure completeness. A piece of gel foam was placed between the rostral and caudal sections of the spinal cord and a piece of dura film was placed over the lesion before the incision was closed.

\section{Spinal Cord Injury Care}

The rats receiving a SCI were given a sub cutaneous injection of $3 \mathrm{~mL}$ of saline for hydration immediately following the spinal cord transection. The rats were also given a $0.5 \mathrm{~mL}$ sub cutaneous injection of Pro Pen G on day 1 for prevention of infection. Starting on day 1 the rats were given a sub cutaneous injection of Ketoprofen $(2.5 \mathrm{mg} / \mathrm{kg}$ body weight; Fort Dodge Animal Health), twice a day for 2 days for analgesia. Also starting on day 1 the rats were given a sub cutaneous injection of Gentamycin $(5 \mathrm{mg} / \mathrm{kg}$ body weight; Hospira Inc, Lake Forest, IL) once a day for 5 days for prevention of possible bladder infection. Following surgery the each animal's bladder was expressed two times a day for 10 days until they became able to void on their own. Surgical clips were removed 7 days after surgery. The general condition of the animal was checked and the perineal area cleaned each time bladder expression was performed. The SCI rats were allowed to recover for 30 days.

\section{Bladder Catheterization}

On day 31 post SCI the rats had a catheter (PE 60, 3.5" length, Intramedic Polyethlene Tubing, Becton Dickinson, Sparks, MD) placed in their urinary bladder to 
allow for the infusion of either 0.5 percent acetic acid mixed with 0.9 percent normal saline or 0.9 percent normal saline alone. The catheter placement was done under $2 \%$ isoflurane (Baxter, Deerfield, IL) sedation. The catheter placement was made by making a $3 \mathrm{~cm}$ midline abdominal incision followed by blunt dissection of the midline abdominal muscles to allow access to the peritoneal cavity. After accessing the peritoneal cavity a purse string suture made with 5.0 nylon was placed in the dome of the bladder and the bladder was incised with microscissors (FST). The catheter was then placed through the incision into the bladder and the purse string suture was tied to anchor the catheter which had a cuff placed at the end. The catheter was tunneled under the skin and exited the rat through an incision just off midline on the dorsum of the rat between the shoulder blades where it was capped and the skin closed with surgical clips (Leica) so future infusions could be made. The abdominal incision was closed in layers. Following the catheterization surgery the animals were given a $0.5 \mathrm{~mL}$ sub cutaneous injection of Pro Pen $\mathrm{G}$ for prevention of infection. They were also given a $5 \mathrm{mg} / \mathrm{kg}$ sub cutaneous injection of Gentamycin once a day for 5 days for prevention of infection.

\section{Bladder Infusion}

Infusions were on days $31,33,35$ post SCI. Each infusion had a volume of $1 \mathrm{~mL}$ of the desired solution, either $0.5 \%$ acetic acid or $0.9 \%$ normal saline and the infusion was performed under $2 \%$ isoflurane sedation. Each infusion lasted 30 minutes and was followed by manual expression of the bladder and by flushing of the urinary bladder with two, $1 \mathrm{~mL}$ infusions of $0.9 \%$ normal saline followed by manual expression of the bladder. Following the infusion on day 35 , the rat was allowed to survive 2 days and was sacrificed on day 37 . 


\section{Tissue Retrieval}

For mRNA expression studies, the rats were perfused with 33 percent RNA Later (Ambion) in exsanguination solution (2.7L distilled water, $27 \mathrm{~g} \mathrm{NaCl}, 5.1 \mathrm{~g}$ Sodium Phosphate monobasic, 42.9g Sodium Phosphate dibasic, total volume 3L). Following perfusion, the nodose ganglia followed by the L6/S1 and L1/L2 dorsal root ganglia, and urinary bladder were extracted. All tissues were placed in RNA later and flash frozen in liquid nitrogen and kept in -80 degree Celsius until RNA extraction. Tissue was collected on $4 \mathrm{SCI}$ animals and 4 naïve animals.

Table 3: SCI + Bladder Inflammation Time Table

\begin{tabular}{|c|c|c|c|}
\hline $\begin{array}{l}\text { SCI + Bladder } \\
\text { Inflammation }\end{array}$ & $\begin{array}{l}\text { Treatment } \\
\text { Dates }\end{array}$ & & \\
\hline Groups & Day 1 & Day 31 & Day 31 \\
\hline $\begin{array}{l}\text { Acetic Acid } \\
n=2\end{array}$ & T8 Transection & Bladder Catheterization & $\begin{array}{l}\text { Acetic Acid } \\
\text { Infusion }\end{array}$ \\
\hline $\begin{array}{l}\text { Normal Saline } \\
n=2\end{array}$ & T8 Transection & Bladder Catheterization & $\begin{array}{l}\text { Normal Saline } \\
\text { Infusion }\end{array}$ \\
\hline & Day 33 & Day 35 & Day 37 \\
\hline $\begin{array}{l}\text { Acetic Acid } \\
\mathrm{n}=2\end{array}$ & $\begin{array}{l}\text { Acetic Acid } \\
\text { Infusion }\end{array}$ & Acetic Acid Infusion & $\begin{array}{l}\text { Tissue } \\
\text { Retrieval }\end{array}$ \\
\hline $\begin{array}{l}\text { Normal Saline } \\
\mathrm{n}=2\end{array}$ & $\begin{array}{l}\text { Normal Saline } \\
\text { Infusion }\end{array}$ & Normal Saline Infusion & $\begin{array}{l}\text { Tissue } \\
\text { Retrieval }\end{array}$ \\
\hline Naïve $n=3$ & & & $\begin{array}{l}\text { Tissue } \\
\text { Retrieval }\end{array}$ \\
\hline
\end{tabular}


Table 4: SCI + Bladder Inflammation Level Effected

\begin{tabular}{|l|l|}
\hline SCI + Bladder Inflammation & Level Effected (DRG) \\
\hline Abdominal Incision & L1/L2 (Presumed) \\
\hline Bladder Catheterization & L1/L2 \\
\hline Acetic Acid Infusion & L1/L2, L6/S1 \\
\hline Normal Saline Infusion & L1/L2, L6/S1 \\
\hline
\end{tabular}

\section{RNA Extraction and Quantitative PCR}

Dorsal root ganglia (DRG) and nodose Ganglia housing neurons innervating the incised tissue were then retrieved. In the SCI + Bladder Inflammation study the L1/L2 and L6/S1 DRG were pooled by animal. In the skin incision study the DRG innervating the incised area were pooled as well. Pooled samples were homogenized on ice using a motorized dual teflon glass homogenizer for 1 minute in 350 ul buffer RLT (Qiagen, Valencia, CA) and 2-mercapto-ethanol. RNA was extracted from the homogenates using the RNeasy plus micro kit (Qiagen) as per manufacturer's protocol. Briefly, homogenates were cleared by centrifugation before selective removal of genomic DNA using the DNA eliminator affinity spin column. RNA was purified by affinity purification using RNA spin columns and eluted in $14 \mathrm{~mL}$ of nuclease-free water. RNA integrity was assessed by UV spectrometry and using a Bioanalyser (Agilent Technologies, Santa Clara, CA). A RNA clean up step was performed with 5M ammonium acetate, glycogen and ethanol precipitation. RNA sample integrity was then reassessed. RNA samples with $260 \mathrm{~nm} / 280 \mathrm{~nm}$ ratios above 1.9 and $260 \mathrm{~nm} / 230 \mathrm{~nm}$ ratios and RNA integrity numbers (RINs) above 1.8 met quality-control standards and 
were used for quantitative PCR.

\section{Quantitative Real-Time PCR}

cDNA was synthesized by addition of reverse transcriptase and reaction buffer. cDNA was synthesized at 25 degrees $\mathrm{C}$ for 5 minutes, 42 degrees $\mathrm{C}$ for 30 minutes and the reverse transcriptase subsequently deactivated by heating to 85 degrees $\mathrm{C}$ for 5 minutes. $5 \mathrm{ng}$ of cDNA template was provided for each PCR reaction (carried out in triplicate). SYBR green QPCR was carried out using a Rotorgene real time PCR detection instrument (Corbett Research, Sydney, Australia). Gene expression values were calculated against the internal reference gene GAPDH. Small differences in QPCR reaction efficiency between primer sets were accounted for using the standard curve quantification method.

\section{Primers}

The P2X3 forward primer sequence was 5' GGCAAGTTCAACATCATCCC and the reverse was 5' AGTCACCTCCTCAAACTTCC. The ATF3 forward primer sequence was 5' GAGATGTCAGTCACCAAGTC and the reverse 5' TTCTTCAGCTCCTCGATCTG.

\section{Data Analysis}

Data analysis was performed in Microsoft Excel and Sigmaplot. Statistics were performed in SPSS and Sigmaplot using one-way ANOVA and post hoc student's t-tests. 


\section{RESULTS}

\section{Single Skin Incision}

Following single skin incision P2X3 mRNA levels appear to decrease at 4 days and remain decreased at 7 and 14 days and return towards baseline at 28 days. A oneway ANOVA determined that there are not significant differences at any time point compared to naïve or each other.

Figure 1:

Single Skin Incision P2X3 mRNA Expression

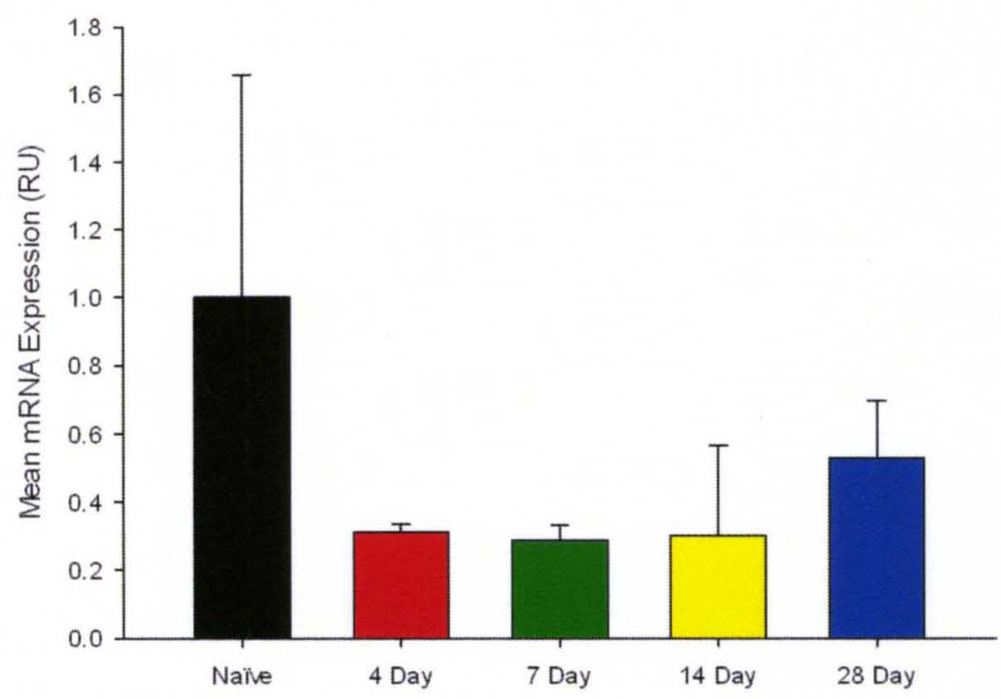

Figure 1: P2X3 mRNA Expression in T5/T6/T7 Dorsal Root Ganglia Following a Single

Skin Incision. Values are mean P2X3 mRNA expression for naïve, 4, 7, 14 and 28 day 
timepoints after a single skin incision (relative units adjusted to naive, normalized to GAPDH). Error bars indicate standard deviation. All groups $n=3$

\section{Double Skin Incision}

A double incision study was also conducted to examine the effects of repeated tissue injury on P2X3 expression. The mRNA levels of P2X3 went from appearing to be down regulated versus naïve in single incision to appearing to be slightly up regulated versus naïve. However, statistical analysis with a one-way ANOVA determined that there are no statistical differences from naïve at either time point or each other. 
Figure 2:

Double Skin Incision P2X3 mRNA Expression

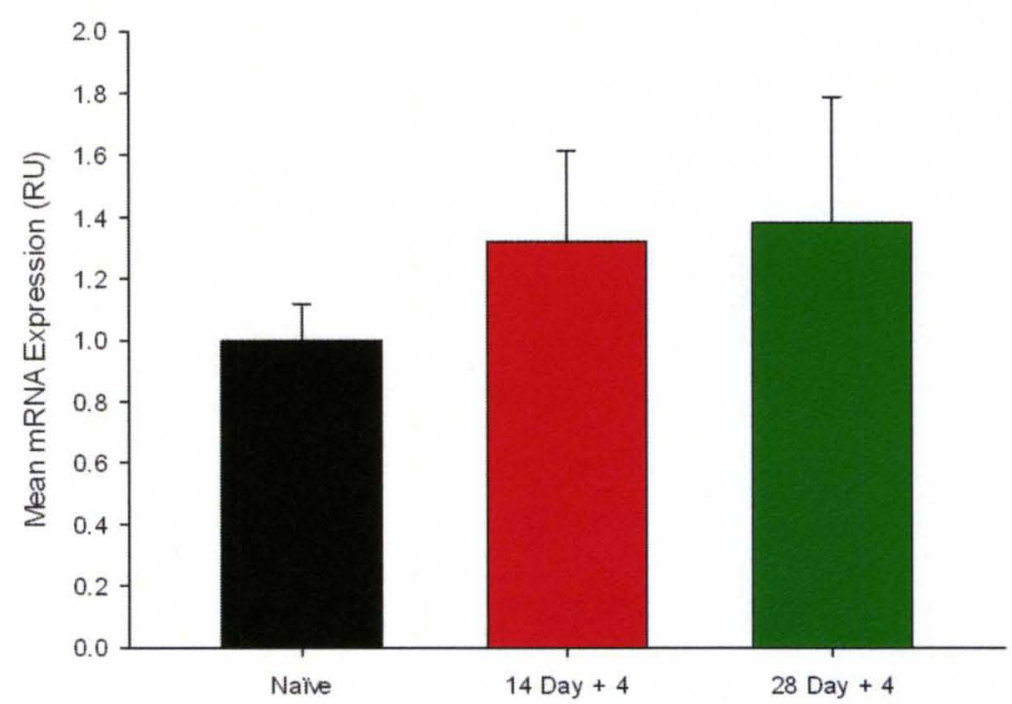

Figure 2: P2X3 mRNA Expression in T5/T6/T7 Dorsal Root Ganglia Following a Double Skin Incision. Values are mean P2X3 mRNA expression for naïve, $14+4$ and $28+4$ day timepoints after a double skin incision (relative units adjusted to naive, normalized to GAPDH). Error bars indicate standard deviation. Naïve $n=4,14+4 n=7$ and $28+4 n=$ 7.

\section{Single Skin Incision versus Double Skin Incision}

Although statistical analysis indicated no significant difference in P2X3 mRNA in either condition compared to naïve, we sought to determine if the regulation of $\mathrm{P} 2 \mathrm{X} 3$ mRNA differed in those conditions. We found that there was a statistical difference (Student's t-test $\mathrm{p}<0.05$ ) when single skin incision was compared to double skin incision. The fold changes of each animal were used to calculate a mean fold changes for each 
experimental group and the results were compared. 14 Day Single Skin Incision was compared to $14+4$ Day Double Skin Incision and 28 Day Single Skin Incision was compared to $28+4$ Day Double Skin Incision. The 4 day single skin incision is shown as well for comparison to the $14+4$ and $28+4$ Day Double Skin Incision.

Figure 3:

14 Day Single Skin Incision vs $14+4$ Day Double Skin Incision

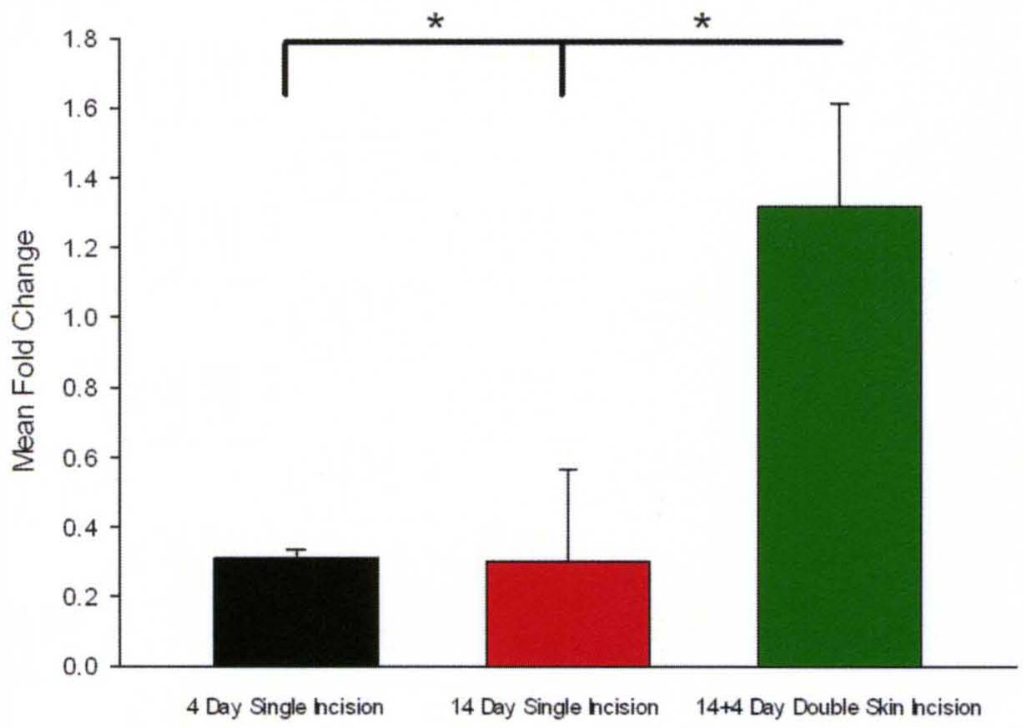

Figure 3: 14 Day Single Skin Incision vs. 14 + 4 Day Double Skin Incision. Values are mean P2X3 fold change for 14 Day Single Incision and 14+4 Day Double Skin Incision. 4 Day $n=3,14$ Day $n=3$ and $14+4 n=7$. Error bars indicate standard deviation. $*=$ Student's t-test $\mathrm{p}<0.05$ 
Figure 4:

28 Day Single Incison vs $28+4$ Day Double Incison

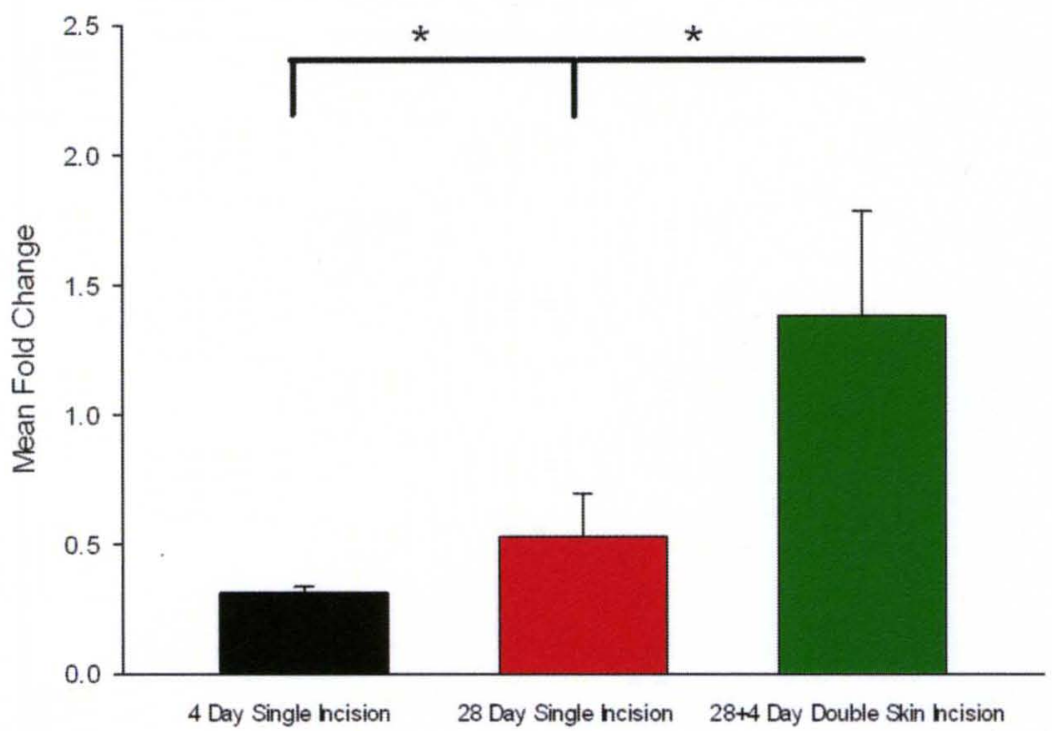

Figure 4: 28 Day Single Skin Incision vs. $28+4$ Day Double Skin Incision. Values are mean P2X3 fold change for 14 Day Single Incision and 14+4 Day Double Skin Incision. 4 Day $n=3,28$ Day $n=3$ and $28+4 n=7$. Error bars indicate standard deviation. $*=$ Student's t-test $\mathrm{p}<0.05$

\section{Bladder Incision}

In order to determine whether the regulation of $\mathrm{P} 2 \mathrm{X} 3$ after skin incision also occurred for damage of visceral tissue, the bladder was incised. It was found that following bladder incision expression levels of P2X3 appear to be reduced. Statistical analysis (Student's t-test) indicated no statistical difference between the two groups but it is approaching significance with a $\mathrm{p}=0.053$. This trend towards reduction follows a similar trend to cutaneous tissue injury for P2X3 expression levels. 
Figure 5:

P2X3 mRNA Expression L1/L2 DRG

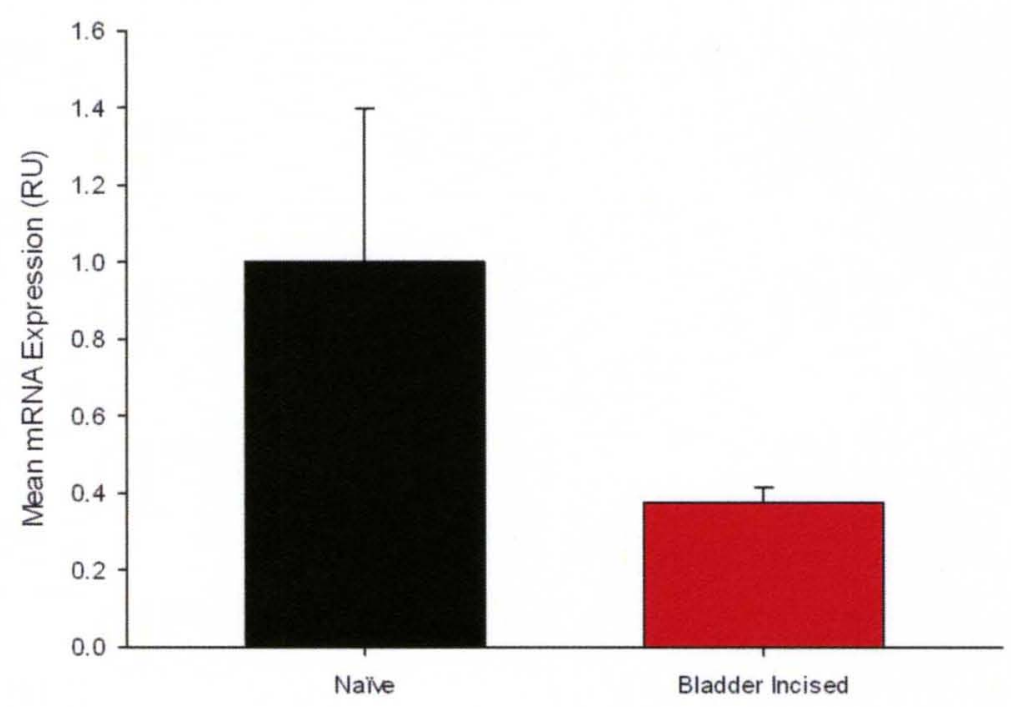

Figure 5: P2X3 mRNA Expression in L1/L2 Dorsal Root Ganglia Following Bladder Incision. Values are mean P2X3 mRNA expression for naïve and bladder incised animals (relative units adjusted to naive, normalized to GAPDH). Error bars indicate standard deviation. Naïve $n=3$, Bladder Incised $n=4$.

\section{SCI plus Bladder Inflammation}

In the study with animals receiving a spinal cord transection and bladder inflammation levels of $\mathrm{P} 2 \mathrm{X} 3$ appeared to be variable with respect to location, $\mathrm{L} 1 / \mathrm{L} 2$ versus L6/S1, however neither result was found to be significant with a one-way ANOVA. ATF3 expression was significant in the L1/L2 dorsal root ganglia but not at L6/S1 using a one-way ANOVA. It was not evident from the data that the acetic acid mediated inflammation caused any difference in the P2X3 or ATF3 levels in the acetic acid versus the normal saline treated animals. The nodose ganglia did not appear to have 
any change for inflamed or non-inflamed SCI rats versus naïve rats for levels of $\mathrm{P} 2 \mathrm{X} 3$ or ATF3.

\section{Effect of Segment on gene regulation with bladder damage}

In order to determine the effect SCI and bladder inflammation has on gene expression, qPCR was run for P2X3 and ATF3 in the L1/L2 and L6/S1 dorsal root ganglia and nodose ganglia. For the L1/L2 dorsal root ganglia, we found that ATF3 expression was significantly up regulated in both the acetic acid and normal saline treated animals as compared to naïve in the L1/L2 dorsal root ganglia (Figure 6). However, P2X3 expression was found to have no change in the L1/L2 dorsal root ganglia (Figure

7). For the L6/S1 dorsal root ganglia, ATF3 expression was not significantly up regulated in the L6/S1 dorsal root ganglia for either the acetic acid or normal saline treated animals as compared to naïve (Figure 8). P2X3 expression in the L6/S1 dorsal root ganglia also had no change for the acetic acid or normal saline treated animals as compared to naïve (Figure 9). We also accessed vagal sensory innervation of the bladder from the nodose ganglia and found there was no change for ATF3 or P2X3 expression in the nodose ganglia in acetic acid treated as compared to naïve animals (Figure 10 and 11). 
Figure 6:

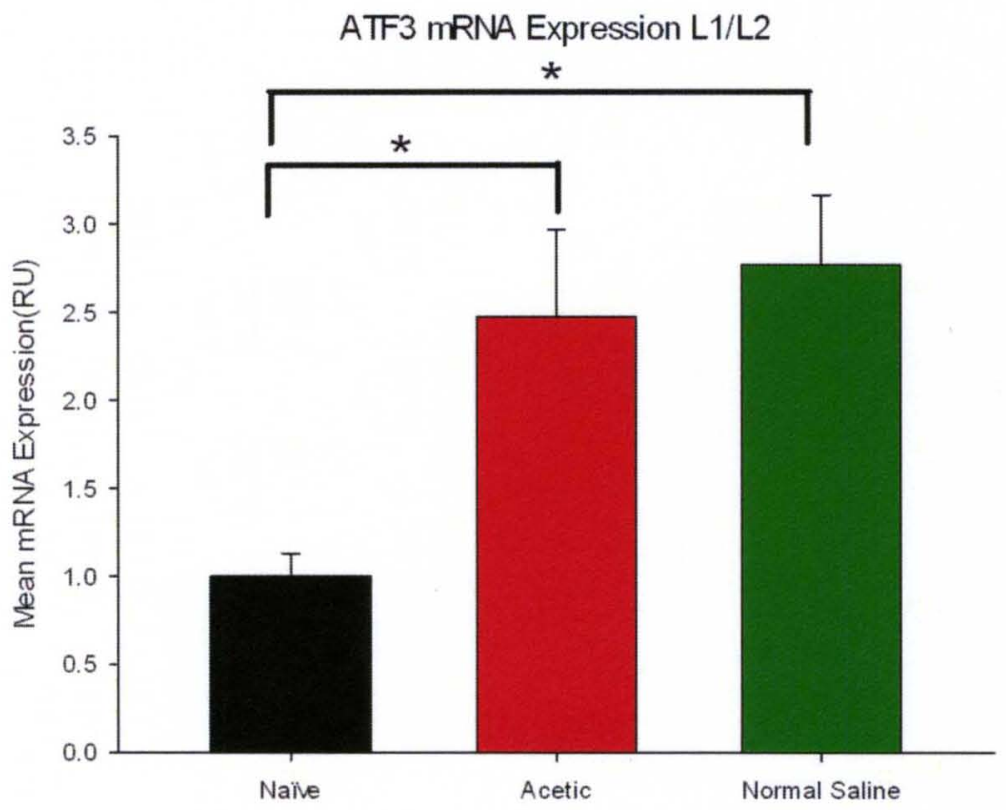

Figure 6: ATF3 mRNA Expression in L1/L2 Dorsal Root Ganglia Following SCI + Bladder Inflammation. Values are mean ATF3 mRNA expression for naïve, acetic acid and normal saline treated after SCI (relative units adjusted to naive, normalized to GAPDH). Error bars indicate standard deviation. Naïve $n=3$, Acetic Acid $n=2$ and Normal Saline $\mathrm{n}=2 .^{*}=$ Student's t-test $\mathrm{p}<0.05$. 
Figure 7:

P2X3 mRNA Expression L1/L2

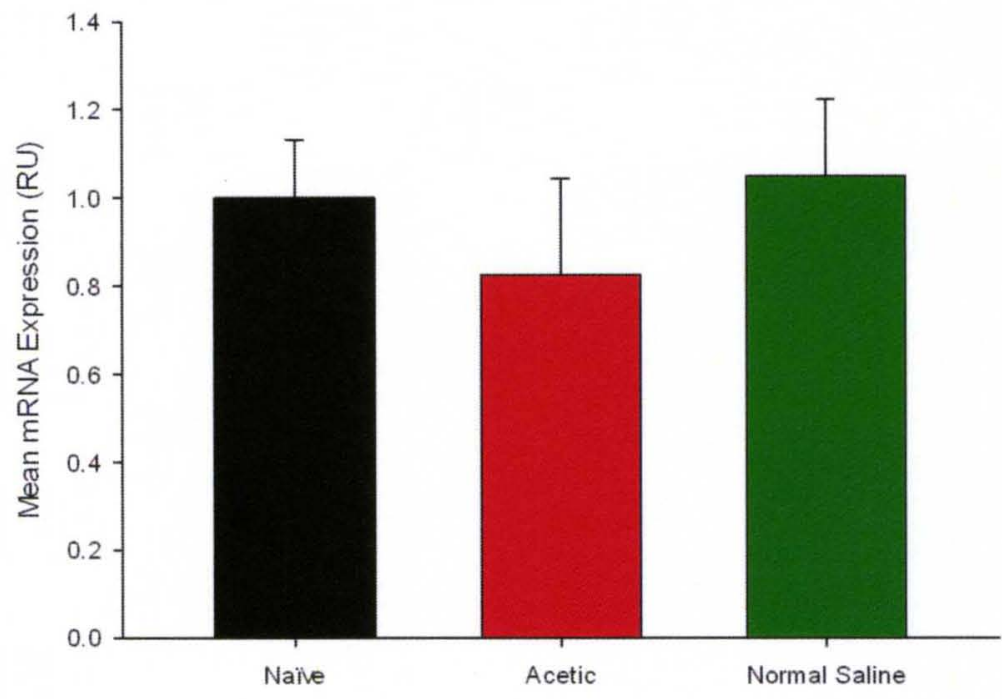

Figure 7: P2X3 mRNA Expression in L1/L2 Dorsal Root Ganglia Following SCI + Bladder Inflammation. Values are mean P2X3 mRNA expression for naïve, acetic acid and normal saline treated after SCI (relative units adjusted to naive, normalized to GAPDH). Error bars indicate standard deviation. Naïve $n=3$, Acetic Acid $n=2$ and Normal Saline $\mathrm{n}=2$. 
Figure 8:

ATF3 mRNA Expression L6/S1

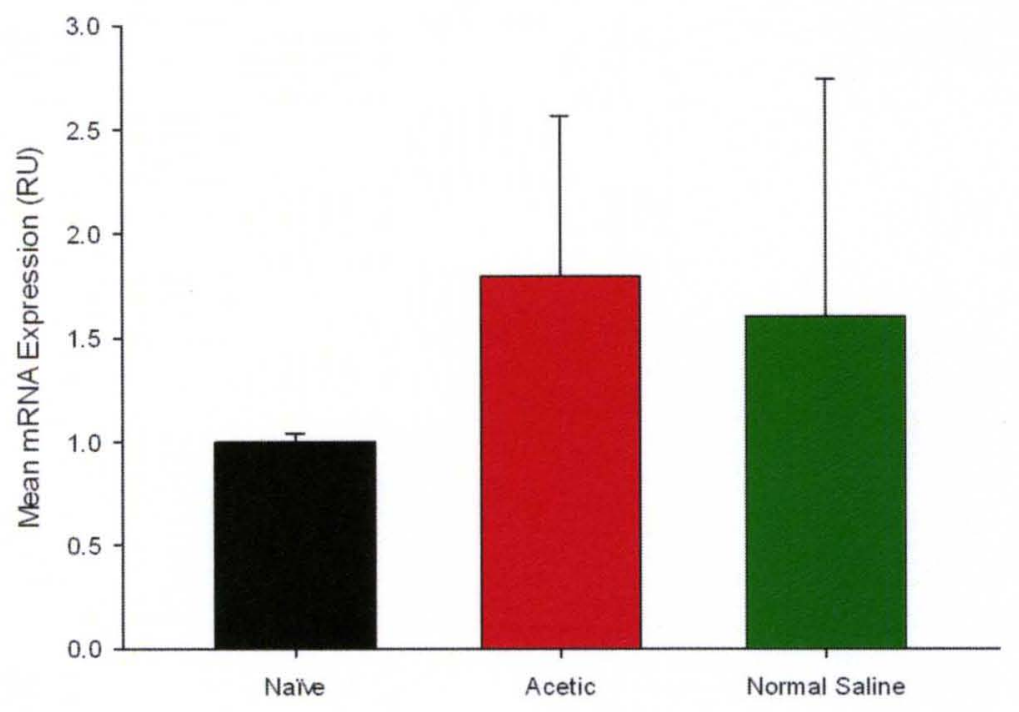

Figure 8: ATF3 mRNA Expression in L6/S1 Dorsal Root Ganglia Following SCI + Bladder Inflammation. Values are mean ATF3 mRNA expression for naïve, acetic acid and normal saline treated after SCI (relative units adjusted to naive, normalized to GAPDH). Error bars indicate standard deviation. Naïve $n=3$, Acetic Acid $n=2$ and Normal Saline $n=2$. 
Figure 9:

P2X3 mRNA Expression L6/S1

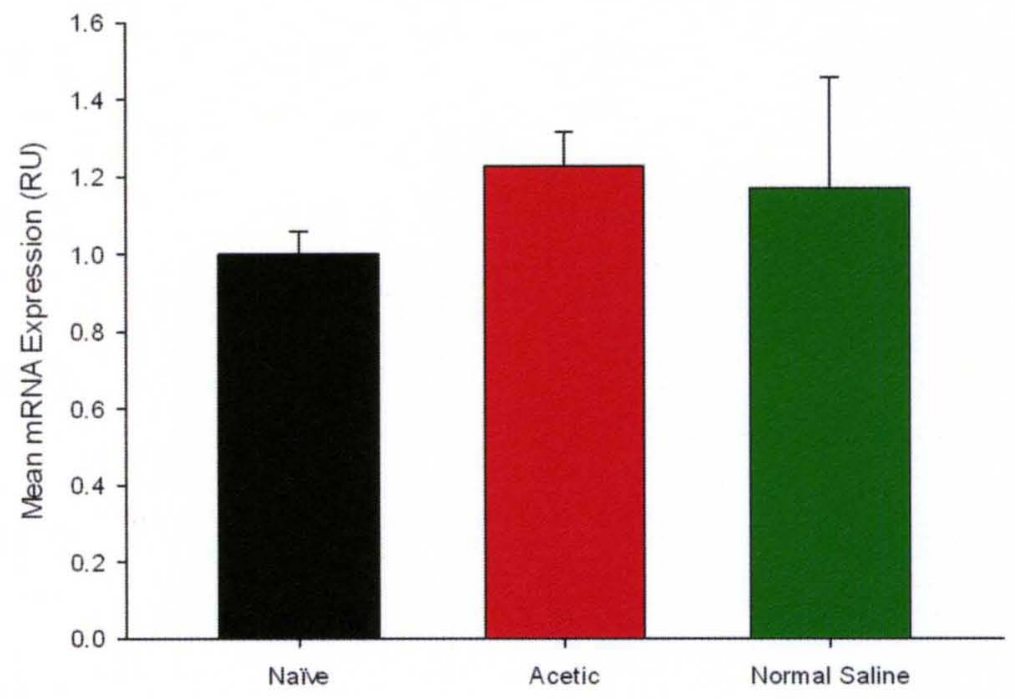

Figure 9: P2X3 mRNA Expression in L6/S1 Dorsal Root Ganglia Following SCI + Bladder Inflammation. Values are mean P2X3 mRNA expression for naïve, acetic acid and normal saline treated after SCI (relative units adjusted to naive, normalized to GAPDH). Error bars indicate standard deviation. Naïve $n=3$, Acetic Acid $n=2$ and Normal Saline $\mathrm{n}=2$. 
Figure 10:

\section{ATF3 mRNA Expression Nodose}

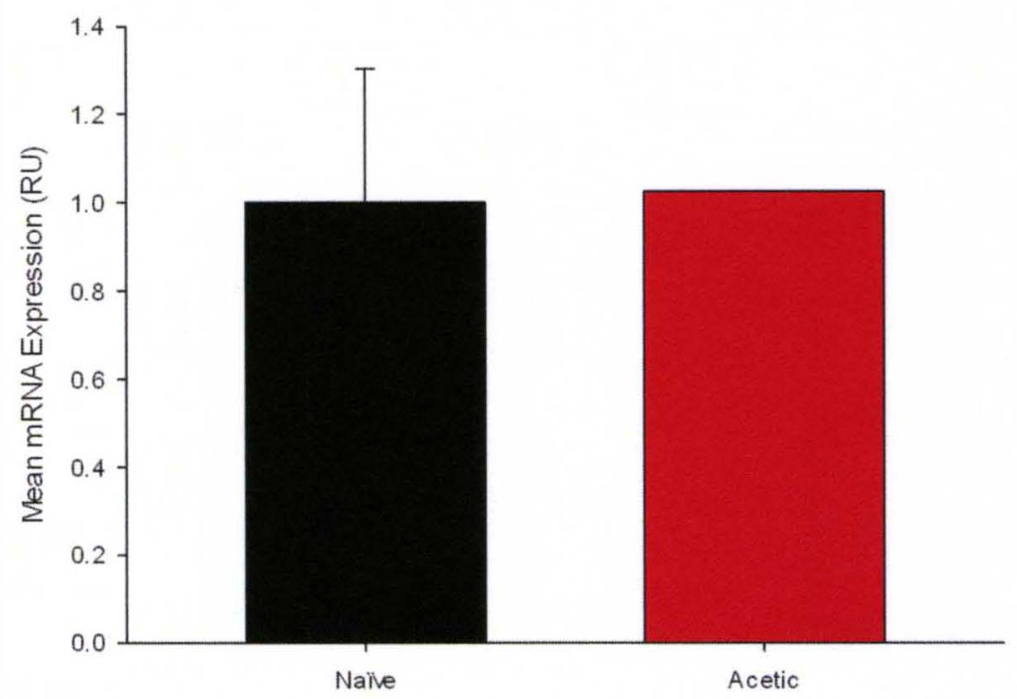

Figure 10: ATF3 mRNA Expression in Nodose Ganglia Following SCI + Bladder

Inflammation. Values are mean ATF3 mRNA expression for naïve, acetic acid treated after SCI (relative units adjusted to naive, normalized to GAPDH). Error bars indicate standard deviation. Naïve $n=3$, Acetic Acid $n=1$. 
Figure 11:

P2X3 mRNA Expression Nodose

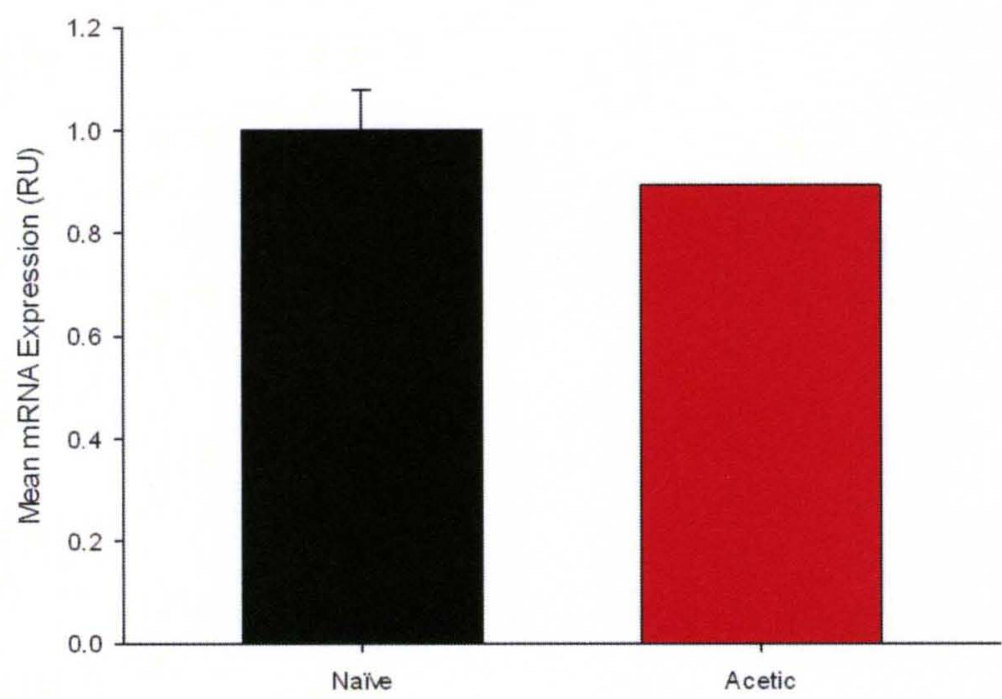

Figure 11: P2X3 mRNA Expression in Nodose Ganglia Following SCI + Bladder Inflammation. Values are mean $\mathrm{P} 2 \mathrm{X} 3 \mathrm{mRNA}$ expression for naïve, acetic acid treated after SCI (relative units adjusted to naive, normalized to GAPDH). Error bars indicate standard deviation. Naïve $n=3$, Acetic Acid $n=1$. 
Table 5: Summary of P2X3 Expression by Experiment

\begin{tabular}{|l|l|}
\hline Experiment & P2X3 mRNA Expression \\
\hline Single Skin Incision vs. Naïve & No Change \\
\hline Double Skin Incision vs. Naive & No Change \\
\hline Bladder Incision vs. Naïve & $\begin{array}{l}\text { Down (Approaching Significance) } \\
\mathrm{p}=0.053\end{array}$ \\
\hline $\begin{array}{l}\text { (14, 28 Day) Single Skin vs. (14+4, 28+4 } \\
\text { SCI+Bladder Inflammation L1/L2 }\end{array}$ & Differential Regulation $\mathrm{p}<0.05$ \\
\hline SCI+Bladder Inflammation L6/S1 & No Change \\
\hline SCI+Bladder Inflammation Nodose & No Change \\
\hline
\end{tabular}




\section{DISCUSSION}

\section{Skin Incision}

We do not know the mechanism of $\mathrm{P} 2 \mathrm{X} 3$ regulation following tissue injury. In the cutaneous injury models $\mathrm{P} 2 \mathrm{X} 3$ expression follows a clear though not statistically different trend by apparently decreasing following initial tissue incision followed by an apparent recovery as the time course extends. After repeated incision of the skin $\mathrm{P} 2 \mathrm{X} 3$ actually "reverses" its regulation and increases after second tissue incision. There is a statistically significant difference between the single skin incision and double skin incision groups when comparing the 14 and $14+4$ day groups and the 28 and $28+4$ day groups. This difference may indicate a switch that could lead to potential pathological changes in sensory neuron function. A switch that may be an indicator of functional priming, which is different then the anatomical and neurochemical priming we discussed earlier. P2X3 up regulation could lead to increased nociceptive signaling.

\section{Bladder Incision}

In the bladder incision without SCI study, P2X3 values are approaching significance with a decrease in expression. While not statistically significant this follows the trend of P2X3 mRNA expression decrease following an initial tissue insult in visceral tissue as well as somatic. Bladder damage might induce damage to sensory neurons. Damage to sensory neurons may lead to changes in gene expression specifically $\mathrm{P} 2 \mathrm{X} 3 \mathrm{in}$ the sensory afferents that innervate the bladder. We have shown that bladder damage 
(i.e. bladder incision) does increase ATF3 expression in sensory neurons innervating the bladder. Bladder inflammation has been shown to sensitize bladder afferents and enhance P2X3 function (Dang et al., 2008), which could lead to bladder hypersensitivity and overactivity. While bladder damage decreases $\mathrm{P} 2 \mathrm{X} 3$ expression in bladder afferents, which could lead to bladder dysfunction.

\section{Bladder inflammation with chronic SCI}

$\mathrm{P} 2 \mathrm{X} 3$ expression in response to SCI and bladder inflammation does not decrease like it does in bladder incision and single skin incision. It trends towards being slightly down regulated at the L1/L2 level and slightly up regulated at the L6/S1 level. However, there is no statistical difference when P2X3 expression is compared for the L1/L2 vs. L6/S1 acetic acid treated animals. A question is could SCI and the general havoc that it creates, particularly in terms of bladder distension and tissue damage be acting as a primary injury to the bladder. With the distension, ATP is being released by the bladder urothelium for $\mathrm{P} 2 \mathrm{X} 3$ receptors to bind and transduce a signal (Burnstock, 2009). More distension could equal more ATP which creates a more intense neural signal than naïve. This increased signal could be acting as a primary insult with the insertion of catheter and irritation by inflammatory agent acting as a secondary injury. This scenario may explain why we would not see a significant decrease in P2X3 following bladder incision and inflammation due to the addition of SCI and the resultant bladder hypertrophy or SCI itself could be acting as a primary injury. Thus, this scenario may act as multiple injuries. 
One way to solve the question of whether resultant bladder hypertrophy from the SCI is responsible for a change in P2X3 expression is to conduct a study where dorsal root ganglia are collected from animals that received only a spinal cord injury. P2X3 expression results from qPCR for the L1/L2 and L6/S1 dorsal root ganglia from those animals could show if $\mathrm{P} 2 \mathrm{X} 3$ expression levels were reduced compared to naïve giving a possible indication that resultant bladder hypertrophy was acting as a primary injury.

While the mechanism of why P2X3 expression decreases following injury to tissue and neurons is unknown, these results could be an indication of a pattern with a variety of tissue injuries triggering a similar response. It is possible that ATF3 may have something to do with the $\mathrm{P} 2 \mathrm{X} 3$ regulation due to its putative binding site on the $\mathrm{P} 2 \mathrm{X} 3$ gene. The trend can be seen that when ATF3 activation occurs, it is accompanied by a decrease in the level of P2X3 mRNA expression in the dorsal root ganglia. This can be seen in the L1/L2 dorsal root ganglia where there is a significant increase in ATF3. It can be observed that there is a slight decrease in the P2X3 expression levels for the acetic acid treated animals as compared to naïve. However, the L6/S1 dorsal root ganglia do not have a significant increase in ATF3 expression. The difference is L6/S1 dorsal root ganglia innervate the portion of the bladder that did not receive an incision. The mRNA expression levels of ATF3 are not significantly increased but the P2X3 expression levels trend towards being slightly elevated. While not significant this could fit the trend of previous studies into the varied results of $\mathrm{P} 2 \mathrm{X} 3$ expression levels with peripheral nerve injury (Tsuzuki et al., 2001). Increased ATF3 expression leads to a decrease in P2X3 levels in the injured neurons while the surrounding uninjured population of neurons in the dorsal root ganglia express increased levels of P2X3 (Tsuzuki et al., 2001). In this case 
the portion of the bladder corresponding to L1/L2 dorsal root ganglia innervation, the dome, received an incision possibly resulting in increased neuronal injury leading to the activation of more ATF3 positive neurons in the dorsal root ganglia slightly lowering the levels of P2X3 mRNA expression in the L1/L2 dorsal root ganglia. However, in the L6/S1 dorsal root ganglia, there was not an incision made in the corresponding innervated tissue leading to a non significant ATF3 activation and overall slightly increased $\mathrm{P} 2 \mathrm{X} 3$ expression in the L6/S1 dorsal root ganglia, which could be due to inflammation without injury to the bladder.

Another consideration is that the abdominal incision that is required to place the bladder catheter presumably injures neurons corresponding to the L1/L2 dorsal root ganglia. This could increase ATF3 activation and mRNA expression in the L1/L2 dorsal root ganglia. This could be addressed for by replicating the abdominal incision (without bladder catheterization) in a group of animals and assessing ATF3 in the L1/L2 dorsal root ganglia.

Another consideration that needs to taken into account is the fact that mRNA expression of genes was being examined by qPCR in the whole dorsal root ganglia. While there may be trends of increased or decreased expression in the dorsal root ganglia as a whole it does not address the question of what is happening to gene expression specifically in the injured neurons. Gene expression changes in these individual neurons that have been injured may be significant while the whole dorsal root ganglion population is not. The gene expression changes in the injured neurons are important in terms of tissue damage. Gene expression changes in injured neurons that could lead to pathological changes in these sensory neurons are of interest. 
The nodose data does not give a clear indication that after SCI the vagus nerve is exhibiting any type of neuronal plasticity indicating its possible innervation of the bladder. However, it does not rule out a connection or a possible link to the incidence of pelvic pain after clinically complete SCI. Anatomical studies have established a connection between the vagus nerve and the rat bladder (unpublished data from Petruska, Hubscher and Rau) and its role and pattern of innervation still need to be elucidated. The role of the vagal innervation may be entirely different than spinal sensory innervation making it unresponsive to injury and inflammation. Another thought is the percentage of nodose neurons innervating the bladder is far too small to reach detection by our methods. In anatomical tracer studies the percentage of neurons labeled by the tracer was very small. 


\section{SUMMARY AND CONCLUSIONS}

We have found that tissue damage may not equal nerve injury but it appears to mimic aspects of it. Its response may have important consequences in terms of sensitization to injury. Repeated injury over time may lead to major havoc in the nervous system and lead to bigger issues such as a transition from acute to chronic pain syndromes in non-SCI patients and may exacerbate autonomic dysreflexia in SCI patients.

Bladder incision and possibly inflammation results in injury to neurons and alteration of expression of the nociceptive marker P2X3. This may or may not indicate a pathological process but it indicates that something is occurring that is different than in naïve. Cutaneous tissue incision has also been shown to alter the level of P2X3. P2X3 plays a role in transduction of the release of ATP by injured tissues into a nociceptive signal. $\mathrm{P} 2 \mathrm{X} 3$ expression is shown to be down regulated after initial tissue injury. We also have shown that following repeated injury it trends to increase slightly, an apparent reversal from its regulation after single incision.

In the future a greater number of animals would be needed to understand whether or not the trends found in the SCI group were true and possibly significant. There would also be the need for a group of SCI animals without abdominal surgery and bladder incision to determine if SCI with bladder dysfunction and hypertrophy is acting as a primary injury and would be responsible for a decrease in P2X3 expression levels. 
An increase in P2X3 may possibly lead to a sensitization like effect in sending more nociceptive signaling messages to the spinal cord. The more frequent the signal the greater the intensity of the signal. While the mechanism is not fully understood an alteration of $\mathrm{P} 2 \mathrm{X} 3$ expression could be part of a pathological conditioning that leads to problems such as chronic pain syndromes for our non SCI population and deadly bouts of autonomic dysreflexia for our SCI population.

While we know the role $\mathrm{P} 2 \mathrm{X} 3$ plays in terms of bladder function and nociceptive signaling in the periphery, future studies will be necessary to understand the role that $\mathrm{P} 2 \mathrm{X} 3$ is playing in terms of changes in its levels of expression. Determining if repeated insults to our cutaneous tissue is capable of bringing about a pathological condition is something worth studying especially if understanding this mechanism can lead to the possible decrease in chronic pain and other pathological pain states. 


\section{REFERENCES}

Anderson KD (2004) Targeting recovery: priorities of the spinal cord-injured population. J Neurotrauma 21:1371-1383.

Applebaum AE, Vance WH, Coggeshall RE (1980) Segmental localization of sensory cells that innervate the bladder. J Comp Neurol 192:203-209.

Basbaum AI, Woolf CJ (1999) Pain. Curr Biol 9:R429-431.

Braz JM, Basbaum AI (2010) Differential ATF3 expression in dorsal root ganglion neurons reveals the profile of primary afferents engaged by diverse noxious chemical stimuli. Pain 150:290-301.

Burnstock G (2009) Purinergic mechanosensory transduction and visceral pain. Mol Pain 5:69.

Center NSCIS (2011) Spinal Cord Injury Facts and Figures at a Glance. National Spinal Cord Injury Statistical Center, Birmingham, Alabama.

Chizh BA, Illes P (2001) P2X receptors and nociception. Pharmacol Rev 53:553-568. Cockayne DA, Hamilton SG, Zhu QM, Dunn PM, Zhong Y, Novakovic S, Malmberg AB, Cain G, Berson A, Kassotakis L, Hedley L, Lachnit WG, Burnstock G, McMahon SB, Ford AP (2000) Urinary bladder hyporeflexia and reduced painrelated behaviour in P2X3-deficient mice. Nature 407:1011-1015.

Cook SP, McCleskey EW (2000) ATP, pain and a full bladder. Nature 407:951-952. 
Dang K, Lamb K, Cohen M, Bielefeldt K, Gebhart GF (2008) Cyclophosphamideinduced bladder inflammation sensitizes and enhances $\mathrm{P} 2 \mathrm{X}$ receptor function in rat bladder sensory neurons. J Neurophysiol 99:49-59.

de Groat WC, Yoshimura N (2010) Changes in afferent activity after spinal cord injury. Neurourol Urodyn 29:63-76.

DeVivo MJ SSL (1995) Long-term survival and causes of death. In: Spinal cord injury: clinical outcomes from the model systems, pp 289-316 Gaithersburg, MD: Aspen Publishers.

Dunn PM, Zhong Y, Burnstock G (2001) P2X receptors in peripheral neurons. Prog Neurobiol 65:107-134.

Ferrari LF, Bogen O, Levine JD (2010) Nociceptor subpopulations involved in hyperalgesic priming. Neuroscience 165:896-901.

Gebhart GF (2004) Descending modulation of pain. Neurosci Biobehav Rev 27:729-737. Hamilton SG, McMahon SB (2000) ATP as a peripheral mediator of pain. J Auton Nerv Syst 81:187-194.

Hill CE, Harrison BJ, Rau KK, Hougland MT, Bunge MB, Mendell LM, Petruska JC (2010) Skin incision induces expression of axonal regeneration-related genes in adult rat spinal sensory neurons. J Pain 11:1066-1073.

Julius D, Basbaum AI (2001) Molecular mechanisms of nociception. Nature 413:203210.

Lu SH, Groat WC, Lin AT, Chen KK, Chang LS (2007) Evaluation of purinergic mechanism for the treatment of voiding dysfunction: a study in conscious spinal cord-injured rats. J Chin Med Assoc 70:439-444. 
McKinley WO, Jackson AB, Cardenas DD, DeVivo MJ (1999) Long-term medical complications after traumatic spinal cord injury: a regional model systems analysis. Arch Phys Med Rehabil 80:1402-1410.

Moss NG, Harrington WW, Tucker MS (1997) Pressure, volume, and chemosensitivity in afferent innervation of urinary bladder in rats. Am J Physiol 272:R695-703.

Neumann S, Skinner K, Basbaum AI (2005) Sustaining intrinsic growth capacity of adult neurons promotes spinal cord regeneration. Proc Natl Acad Sci U S A 102:1684816852.

North RA (2004) P2X3 receptors and peripheral pain mechanisms. J Physiol 554:301308.

Sandkuhler J (1996) The organization and function of endogenous antinociceptive systems. Prog Neurobiol 50:49-81.

Stam FJ, MacGillavry HD, Armstrong NJ, de Gunst MC, Zhang Y, van Kesteren RE, Smit AB, Verhaagen J (2007) Identification of candidate transcriptional modulators involved in successful regeneration after nerve injury. Eur J Neurosci $25: 3629-3637$.

Subramanian A, Tamayo P, Mootha VK, Mukherjee S, Ebert BL, Gillette MA, Paulovich A, Pomeroy SL, Golub TR, Lander ES, Mesirov JP (2005) Gene set enrichment analysis: a knowledge-based approach for interpreting genome-wide expression profiles. Proc Natl Acad Sci U S A 102:15545-15550.

Teasell RW, Arnold JM, Krassioukov A, Delaney GA (2000) Cardiovascular consequences of loss of supraspinal control of the sympathetic nervous system after spinal cord injury. Arch Phys Med Rehabil 81:506-516. 
Tsujino H, Kondo E, Fukuoka T, Dai Y, Tokunaga A, Miki K, Yonenobu K, Ochi T, Noguchi K (2000) Activating transcription factor 3 (ATF3) induction by axotomy in sensory and motoneurons: A novel neuronal marker of nerve injury. Mol Cell Neurosci 15:170-182.

Tsuzuki K, Kondo E, Fukuoka T, Yi D, Tsujino H, Sakagami M, Noguchi K (2001) Differential regulation of P2X(3) mRNA expression by peripheral nerve injury in intact and injured neurons in the rat sensory ganglia. Pain 91:351-360. 


\section{CURRICULUM VITAE}

NAME:

ADDRESS:

DOB:

EDUCATION

\& TRAINING:
Sean Anthony Trusty

2219 Stephan Lane

Louisville, KY 40214

Louisville, KY - December 14, 1984

B.S., Biology

University of Kentucky

$2003-2007$ 